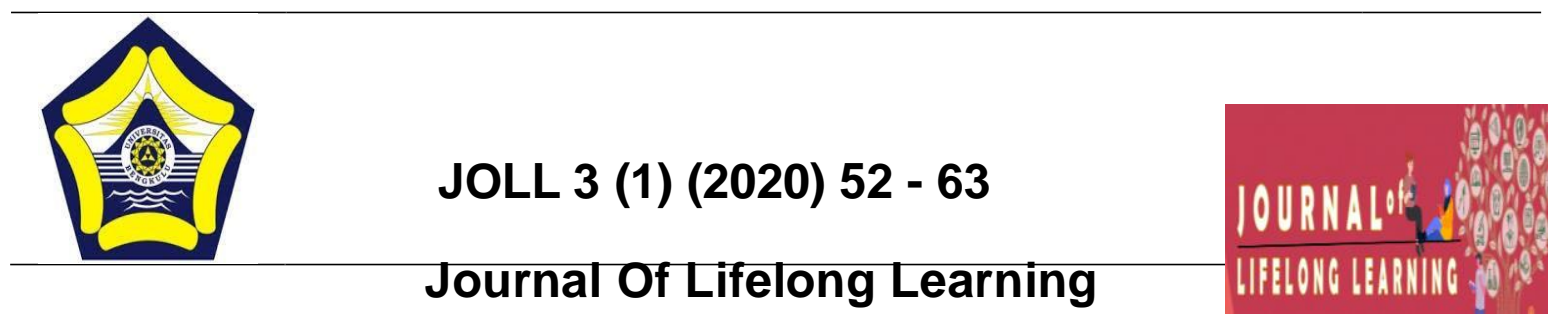

\title{
KORELASI ANTARA PENGGUNAAN GADGET DI RUMAH DENGAN PERKEMBANGAN SOSIAL EMOSIONAL ANAK USIA DINI DI PAUD DELLIA CREATIVE SCHOOL
}

\section{Try Yunita Damayanti ${ }^{1}$,Agus Zainal ${ }^{2}$,Suardi Jasma ${ }^{3}$}

${ }^{1}$ Try Yunita Damayanti, Universitas Bengkulu, Indonesia, dtryyunita@yahoo.com

${ }^{2}$ Agus Zainal, Universitas Bengkulu, Indonesia, aguszainal82@yahoo.com

${ }^{3}$ Suardi Jasma, Universitas Bengkulu, Indonesia, suardijasma@gmail.com

\begin{abstract}
Innovation of the latest technology with better capabilities and latest features that have the purpose or function to be more practical and useful or gadget. As it grows, the definition of gadget is growing into a wider anyway. Many people assume that smartphone is a gadget. There is also a thought that the computer or laptop with new technology is gadget. The purpose of this study was to determine the correlation between the used of gadget at home with social emotional development of children aged 3-5 years in PAUD Dellia Creative School. This research used a correlational study with quantitative approach. Samples were taken by using purposive sampling as many as 37 respondents.

The instrument used in this study was a questionnaire, by using indirectly questionnaires. The statistical test by using the formula of product moment correlation, with an error rate $(\alpha)=0.05$. The research results get the value of $t_{\text {count }}$ is 1.26 and $t_{\text {table }}$ is 1.6905 . Value of correlation between the used of gadget with social emotional development of children aged 3-5 years is 0.21 , which means the correlation is very low. The conclusion of this research that there is no significant correlation between the used of gadget at home with social emotional development of children aged 3-5 years in PAUD Dellia Creative School.
\end{abstract}

Key words: Correlation, The used of gadget, Social Emotional Development of Children.

\section{$\square$ Addresscorrespondence:}

Jl.W.R.Supratman,KandangLimun,MuaraBangkaHulu, KotaBengkulu,Bengkulu38371 


\section{Pendahuluan}

Pendidikan merupakan hal yang paling pokok dalam aspek kehidupan manusia, sehingga manusia dalam kesehariannya tidak luput dari kegiatan pendidikan. Pendidikan adalah proses pembentukan kecakapan-kecakapan fundamental secara intelektual dan emosional kearah alam dan sesama manusia (John Dewey dalam Hasbullah, 2013:2). Kegiatan pendidikan tidak hanya wajib, namun merupakan suatu kebutuhan yang dapat ditempuh melalui berbagai jenis pendidikan. Berdasarkan UU No. 20 Tahun 2003 tentang Sistem Pendidikan Nasional, bahwa pendidikan itu dilaksanakan melalui tiga jalur yaitu, pendidikan formal, pendidikan nonformal, dan pendidikan informal.

Menurut Ahmadi (2015 : 164) Pendidikan Nonformal atau Pendidikan Luar Sekolah (PLS), ialah semua bentuk pendidikan yang diselenggarakan dengan sengaja, tertib dan berencana, di luar kegiatan persekolahan. Selain itu pendapat lain tentang pendidikan luar sekolah dikemukakan, Mazuki (2009 :136) Proses belajar terjadi secara terorganisasikan di luar sistem persekolahan atau pendidikan formal, baik dilaksanakan secara terpisah maupun merupakan bagian penting dari suatu kegiatan yang lebih besar yang dimaksudkan untuk melayani sasaran didik tertentu dan belajarnya tertentu pula.

Bedasarkan pendapat para ahli diatas dapat disimpulkan bahwa Pendidikan Non Formal adalah suatu kegiatan pendidikan yang dilakukan secara sengaja, terstruktur, dan berlangsung di luar sistem persekolahan. Dalam program pendidikan non formal sebagaimana tercantum dalam UU No. 20 Tahun 2003 pada pasal 26 ayat 3 tentang Sistem Pendidikan Nasional terdiri dari Pendidikan Kecakapan Hidup, Pendidikan Anak Usia Dini, Pendidikan Kepemudaan, Pendidikan Pemberdayaan Perempuan, Pendidikan Keaksaraan, Pendidikan Keterampilan Dan Pelatihan Kerja, Pendidikan Kesetaraan serta pendidikan lain yang ditujukan untuk mengembangkan kemampuan peserta didik.

Salah satu kebijakan pemerintah di sektor pendidikan yang mendukung pendidikan sepanjang hayat adalah diakuinya Pendidikan Anak Usia Dini (PAUD), dimana pendidikan anak usia dini merupakan pendidikan yang cukup penting dan bahkan menjadi landasan 
kuat mewujudkan generasi yang cerdas dan kuat. Oleh karena itu pendidikan sejak dini harus ditanamkan sejak awal.

Berdasarkan Undang Undang Nomor 20 Tahun 2003 Tentang Sistem Pendidikan Nasional berkaitan dengan Pendidikan Anak Usia Dini tertulis pada pasal 28 ayat 1 yang berbunyi "Pendidikan Anak Usia Dini diselenggarakan bagi anak sejak lahir sampai dengan enam tahun dan bukan merupakan prasyarat untuk mengikuti pendidikan dasar". Selanjutnya, pada Bab 1 pasal 1 ayat 14 ditegaskan bahwa pendidikan anak usia dini adalah suatu upaya pembinaan yang ditujukan kepada anak sejak lahir sampai dengan usia enam tahun yang dilakukan melalui pemberian rangsangan pendidikan untuk membantu pertumbuhan dan perkembangan jasmani dan rohani anak agar memiliki kesiapan untuk pendidikan lebih lanjut (Depdiknas, USPN, 2004 : 4). Pendidikan anak usia dini merupakan salah satu bentuk penyelenggaraan pendidikan yang menitikberatkan pada peletakan dasar ke arah pertumbuhan dan perkembangan fisik (koordinasi motorik halus dan kasar), kecerdasan (daya pikir, daya cipta, kecerdasan emosi, kecerdasan spritual), sosio emosional (sikap dan perilaku serta beragama), bahasa dan komunikasi, sesuai dengan keunikan dan tahap-tahap perkembangan yang dilalui anak usia dini.

Sejalan dengan amanat UU tersebut di atas, Permendiknas No. 58 Tahun 2009 menyatakan bahwa terdapat tingkat pencapaian perkembangan yang menggambarkan harapan pencapaian pertumbuhan dan perkembangan anak pada rentang usia tertentu, yang di dalamnya terdapat lima aspek perkembangan. Aspek-aspek perkembangan tersebut yaitu: (1) aspek perkembangan Nilai Moral dan Agama, (2) aspek perkembangan Fisik/Motorik, (3) aspek perkembangan Kognitif, (4) aspek perkembangan Bahasa, (5) aspek perkembangan Sosial Emosional, lima aspek ini diharapkan berkembang dengan sangat baik.

Artinya bahwa anak usia dini mengalami perkembangan dan pertumbuhan berdasarkan pendapat yang diuraikan diatas, dapat disimpulkan bahwa anak usia dini adalah anak yang berusia nol sampai enam tahun yang akan melewati setiap aspek pertumbuhan dan perkembangan baik itu kognitif, bahasa, motorik, sosial emosional, moral agama, dan seni. 
Menurut Soetjiningsih (2012: 264) Perkembangan sosial dan emosi adalah proses berkembangannya kemampuan anak untuk menyesuaikan diri terhadap dunia sosial yang lebih luas. Dalam proses perkembangan ini anak diharapkan mengerti / memahami orang lain yang berarti mampu menggambarkan ciri-cirinya mengenali apa yang dipikirkan, dirasa dan diinginkan serta dapat mendapatkan diri pada sudut pandang orang lain tersebut tanpa "kehilangan" dirinya.

Berdasarkan pendapat para ahli diatas dapat disimpulkan bahwa perkembangan sosial-emosional anak adalah kemampuan anak menyesuaikan diri dengan lingkungan dalam berperilaku sesuai dengan tuntunan sosial, baik perilaku terhadap teman sebaya, keluarga maupun masyarakat dan sekolah.

Pendidikan anak usia dini yang dilakukan baik dalam keluarga, sekolah maupun masyarakat hendaklah dapat mencakup seluruh aspek perkembangan anak melalui kegiatan yang menyenangkan. Dimana dalam pendidikan anak usia dini berbicara mengenai seluk beluk pendidikan anak yang tidak lepas dari masalah tentang petumbuhan dan perkembangan anak. Namun di era globalisasi saat ini anak tidak lagi sesuai dengan perkembangan yang seharusnya, dimana anak seharusnya dalam masa perkembangannya dapat berinteraksi dengan teman sebayanya.

Dewasa ini, alat elektronik serba canggih, anak pun ikut menikmati canggihnya elektronik yang diperkenalkan oleh orang tuanya, salah satunya yaitu gadget yang sudah banyak beredar dengan banyak aplikasi yang sangat mudah digunakan oleh anak usia dini saat ini. Tanpa disadari orang tua, bahwa gadget dapat memberikan dampak untuk anak baik diawasi maupun tidak diawasi, dan baik dampak negatif maupun positif. Gadget bisa saja memberikan dampak yang positif terhadap anak yaiu dengan fitur-fitur pengajaran yang ada di dalam gadget, misalnya melaui aplikasi Alquran atau Alkitab dan pembelajaran lain anak menjadi lebih mudah menghafal, menginagat, namun dampak negatifnya adalah karena aplikasi tersebut anak menjadi lebih fokus kepada gadgetnya dan akhirnya mengabaikan lingkungan sekitarnya, dimana anak dalam masa emasnya adalah bermain sambil belajar. 
Seperti seharusnya bermain dengan teman sebayanya.

Belum lagi adanya aplikasi permainan di dalam gadget tersebut yang mudah di tiru oleh anak usia dini dan bisa saja mempraktiknya kepada temannya. Oleh karena itu anak menjadi susah lepas dari gadget, anak menjadi kecanduan dengan aplikasi yang bisa mempermudahnya dalam pembelajaran mengahafal, mengenal warna, dan juga permainan-permainan yang menarik anak untuk terus bermain, contohnya saja permainan Pou dan permainan lainnya.

Gadget merupakan sebuah inovasi dari teknologi terbaru dengan kemampuan yang lebih baik dan fitur terbaru yang memiliki tujuan maupun fungsi lebih praktis dan juga lebih berguna.

Seiring perkembangan pengertian gadget pun menjadi berkembang yang sering kali menganggap smartphone adalah sebuah gadget dan juga teknologi komputer atau pun laptop bila telah diluncurkan produk baru juga dianggap sebagai gadget (Hamdiyah Rofiati, 2012).

Diungkapkan oleh Widiawati, Hendra, dan Edy (2014:10) Bahwa dampak yang terbesar dalam menggunakan aplikasi gadget di era digital ini, salah satunya adalah anak akan mengalami hambatan dalam setiap aspek perkembangan, diantaranya; kognitif, bahasa, motorik, sosial emosional, dan moral. Setiap hambatanhambatan tersebut akan berpengaruh langsung pada perkembangan anak selanjutnya.

Dijelaskan kembali oleh Widianawati Audio yang keluar dari games tersebut, terkadang mengeluarkan suara-suara yang mungkin belum seharusnya didengar oleh mereka. Sehingga hal-hal tersebut dapat mudah terekam oleh anak-anak dimasa the golden age. Hal ini karena pada masa tersebut biasanya ditandai oleh perubahan cepat dalam perkembangan fisik, kognitif, sosial, dan emosional

Menurut penelitian Nielsen, sebanyak $40 \%$ anak usia 0-8 tahun sudah mengenal gadget seperti smartphone, ipod, atau ipad. Alasannya sederhana, agar si anak punya keasyikan sendiri saat orang tua mereka sibuk. Namun, sebanyak $77 \%$ orang tua berpikir bahwa komputer tablet seperti ipad sangat berguna bagi anak-anak mereka. Angka serupa menyatakan bahwa tablet dapat membuat anak-anak kreatif. Untuk 
membuat anak-anak tertarik bermain tablet, sebanyak $25 \%$ orang tua sengaja mengunduh aplikasi yang menarik buat mereka. Aplikasi tersebut $46 \%$ adalah games atau teka-teki yang menyenangkan, $42 \%$ yang mengandung unsur edukasi, dan $28 \%$ yang dianggap dapat memancing kreativitas anak. (Tim Internet Sehat, 2012).

Dari pendapat para ahli di atas dapat di simpulkan penggunaan gadget memberikan dampak kepada penggunanya. Kemudahan dalam bidang teknologi membuat pengguna mempunyai pendapat yang berbeda dalam konteks akibat setelah menerima teknologi tersebut. Ada dampak positif yaitu meningkatkan semangat belajar anak, tetapi juga ada dampak negatifnya yaitu berdampak pada kemalasan, karena anak-anak lebih mementingkan gadgetnya daripada pembelajarannya. Dengan adanya gadget anak juga menjadi bersifat individual, kurang berinteraksi dengan lingkungan akibat fokus pada gadget yang dipegangnya, dan menjadi emosi jika diganggu saat bermain gadget.

Karena keunggulan aplikasi gadget, maka dengan pengawasan orang dewasa gadget lebih pantas digunakan untuk mengembangkan suatu pikiran, ide, usaha dan gaya hidup remaja atau orang dewasa atau orang yang memiliki kepentingan khusus dalam penggunaan gadget. Bukan hanya sekedar dijadikan sebagai media hiburan, untuk nge-games atau menonton suatu acara secara online (menggunakan aplikasi televisi online atau youtube) untuk anak usia dini.

Berdasarkan data yang peneliti peroleh dari PAUD Dellia Creative School pada tahun 2016 menurut usia anak yaitu : anak usia 7 tahun ada 4 anak, anak usia 6 tahun ada 12 anak, anak usia 5 tahun ada 20 anak, anak usia 4 tahun ada 14 anak, anak usia 3 tahun ada 8 anak, anak usia 2 tahun ada 39 anak, anak usia 1 tahun ada 8 anak. Total 105 anak, dan total anak usia 3-5 tahun ada 42 anak. Berdasarkan informasi sementara dari salah seorang guru di PAUD Dellia bahwa beberapa orang tua anak memiliki kesibukkan atas pekerjaannya sehingga beberapa orang tua memfasilitasi gadget di rumah untuk anaknya sejak usia 3 tahun, dengan tujuan agar anak tidak rewel dan mau menuruti perintah orangtuanya serta tidak mengganggu kesibukkan orangtuanya. Dan berdasarkan informasi sementara yang di dapat peneliti dari salah seorang guru di PAUD Dellia bahwa beberapa anak ada 
yang kurang bersosialiasi dengan temannya dan ada juga ada beberapa anak yang lebih cepat emosi.

Diketahui bahwa alasan orang tua memberikan fasilitas gadget kepada anak usia 3-5 tahun ialah agar anak tidak rewel dan betah di dalam rumah, dan orangtua tidak menyadari akibat dari penggunaan gadget, anak lebih banyak menghabiskan waktunya bermain gadget dibandingkan bermain dengan teman di lingkungannya dan menghabiskan waktu dengan orang tuanya. Anak juga lebih cepat emosi dan tidak bisa berlama-lama jauh dari gadgetnya.

Lebih memprihatinkan lagi orang tua memberikan gadget untuk mendiamkan anaknya dan orang tua tidak menyadari bahwa kegiatan bermain gadget yang berlebihan dan menggunakan waktu yang cukup lama akan banyak menyita waktu bagi anak untuk melakukan hal yang lainnya. Hal ini akan mengakibatkan anak menjadi orang yang kurang empati dengan situasi disekitarnya dan anak akan lebih fokus dengan gadget dibandingkan berbagi dan bermain bersama teman dan lingkungannya. Sedangkan anak yang tidak memiliki gadget akan lebih mudah berkomunikasi dengan teman-temannya atau bermain dengan teman-temannya.
Untuk memperoleh data yang sesungguhnya peneliti tertarik untuk melihat adakah hubungan yang signifikan antara penggunaan gadget di rumah dengan perkembangan sosial emosional anak usia 3-5 tahun di PAUD Dellia Creative School.

\section{Metode}

Penelitian ini menggunakan penelitian korelasional dengan pendekatan kuantitatif. Lokasi dalam penelitian ini adalah PAUD Dellia Creative School. Populasi dalam penelitian ini sebanyak 43 anak, sedangkan sampelnya adalah 37 anak dengan menggunakan sampling purposive sesuai dengan teori Sugiyono (2006 : 90), dengan pertimbangan hanya anak yang menggunakan gadget saja yang dijadikan sampel. teknik pengumpulan data menggunakan kuesioner/angket sebagai data utama dan dokumentasi sebagai data pendukung. Instrumen dalam penelitian ini menggunakan angket uji coba yaitu angket di sebar terlebih dahulu ke orang tua anak di TK Islam Al Azhar 50 Kota Bengkulu. Untuk teknik analisis data dalam penelitian ini adalah dengan rumus Product Moment. 
Adapun rumus Product Moment yang dimaksud adalah sebagai berikut :

$$
r_{x y}=\frac{N \sum X Y-\left(\sum X\right)\left(\sum Y\right)}{\sqrt{\left\{N \sum X^{2}-\left(\sum X\right)^{2}\right\}\left\{N \sum Y^{2}-\left(\sum Y\right)^{2}\right\}}}
$$

Keterangan:

1. $\mathrm{N}=$ Jumlah responden

2. $\mathrm{X}=$ Skor variabel (jawaban responden)

3. $\mathrm{Y}=$ Skor total variabel untuk responden $\mathrm{n}$

\section{Hasil dan Pembahasan}

Setelah melakukan uji normalitas, uji linieritas regresi dan korelasi product moment, diketahui bahwa nilai interprestasi korelasi sebesar 0,0441 yang artinya korelasi sangat rendah, maka dapat disimpulkan penggunaan gedget di rumah memberikan kontribusi atau sumbangan sebesar 4, 41 persen terhadap perkembangan sosial emosional anak usisa 3-5 tahun di PAUD Dellia Creative School dan sisanya 95,59 persen ditentukan oleh variabel lain.

Dari hasil perhitungan ini berarti hubungan antara penggunaan gadget di rumah dengan perkembangan sosial emosional anak usia 3-5 tahun adalah sangat rendah. Artinya anak usia 3-5 tahun di PAUD Dellia Creative School mengikuti tahap perkebangan anak menurut Undang-undang Nomor 58 tahun 2009, misalnya anak usia 3-4 tahun bisa bersabar menunggu giliran, mulai menunjukkan sikap, toleran sehingga dapat bekerja dalam kelompok, dan lainlain, serta anak usia 4-5 tahun dapat menunjukkan sikap mandiri dalam memilih kegiatan, mau berbagi, menolong, dan membantu teman. Pendidik atau guru di PAUD Dellia Creative School juga mampu membentuk perkembangan sosial emosional anak sehingga anak yang sering bermain gadget mampu berperilaku sosial dengan baik, karena sekolah merupakan lingkungan kedua bagi anak setelah keluarga, di sekolah anak berhubungan dengan guru dan teman-teman sebayanya.

Hubungan antara guru dan anak dengan teman sebaya dapat mempengaruhi perkembangan emosi dan sosial anak. Guru merupakan wakil dari orang tua mereka saat mereka berada di sekolah serta pola asuh dan perilaku yang ditampilkan oleh guru dihadapan anak juga dapat mempengaruhi emosi dan sosial anak.

Meskipun hubungan antara penggunaan gadget di rumah dengan perkembangan sosial emosial anak di sekolah hasilnya menunjukkan kontribusi 
yang sangat rendah dan tidak memiliki hubungan yang signifikan orang tua dan pendidik tetap perlu mendampingi dan mengarahkan penggunaan gadget sesuai dengan kebutuhan yang diperlukan oleh anak.

Wiyani (2016 : 102) mengemukakan ada tiga faktor yang memperngaruhi perkembangan sosial emosional anak yaitu faktor heriditas, faktor lingkungan, dan faktor umum.

Berdasarkan hasil uji $t_{\text {hitung tidak }}$ terdapat hubungan yang signifikan antara penggunaan gadget di rumah dengan perkembangan sosial emosional anak yang di dapat dari hasil penyebaran angket ke orang tua anak dan ke pendidik atau guru.

Berdasarkan hasil penelitian gadget memiliki hubungan yang sangat rendah dengan perkembangan sosial emosional anak, dan berdasarkan perhitungan $t_{\text {hitung }}$ tidak ada hubungan yang signifikan antara gadget dengan perkembangan sosial emosional anak usia 3-5 tahun di PAUD Dellia Creative School. Hal ini sejalan dengan penelitian yang dilakukan oleh Karman (2013) peneliti menunjukan bahwa anak-anak usia 6 tahun ke bawah sudah terlibat dalam penggunaan media dan teknologi baru semenjak lahir. Orang tua dan anggota keluarga lainnya pun menjadi faktor pendukung dalam pola pembelajaran tersebut, sehingga media dan teknologi baru memainkan peranan penting tetapi tidak merampas kegiatan luang mereka.

Penelitian ini juga sejalan dengan Jovita Maria Ferliana, M.Psi., Psikolog dari RS Royal Taruma (dalam Prianggoro : 2016) : Sebetulnya, dampak positif gadget ialah gadget akan membantu perkembangan fungsi adaptif seorang anak. Artinya kemampuan seseorang untuk bisa menyesuaikan diri dengan keadaan lingkungan sekitar dan perkembangan zaman. Jika perkembangan zaman sekarang muncul gadget, maka anak pun harus tahu cara menggunakannya.

Artinya adalah gadget tidak berpengaruh besar dengan perkembangan sosial emosional anak jika orang tua mampu memberikan batasan waktu anak bermain gadget. "Anak usia di bawah 5 tahun, boleh-boleh saja diberi gadget. Tapi harus diperhatikan durasi pemakaiannya," saran Jovita (dalam Prianggoro : 2016). Misalnya, boleh bermain tapi hanya setengah jam dan hanya pada saat senggang. Contohnya, kenalkan gadget seminggu sekali, 
misalnya hari Sabtu atau Minggu. Lewat dari itu, ia harus tetap berinteraksi dengan orang lain. Aplikasi yang boleh dibuka pun sebaiknya aplikasi yang lebih ke fitur pengenalan warna, bentuk, dan suara.

Hal ini tidak sejalan dengan peneltian Diungkapkan oleh Widiawati, Hendra, dan Edy (2014:10). Bahwa dampak yang terbesar dalam menggunakan aplikasi gadget di era digital ini, salah satunya adalah anak akan mengalami hambatan dalam setiap aspek perkembangan, diantaranya; kognitif, bahasa, motorik, sosial emosional, dan moral. Setiap hambatanhambatan tersebut akan berpengaruh langsung pada perkembangan anak selanjutnya.

Penelitian ini juga bertolak belakang dengan Astrid Wulansari Emeline N., M. Psi. (Psikologi Anak). Pada ketika anak terlalu sering bermain gawai, anak akan kurang human-being, kurang manusiawi, dan tidak memiliki empati rasa. Jangka panjangnya, anak akan tidak punya regulasi diri yang baik karena tidak memiliki pengalaman dan interaksi sosial yang cukup di dunia nyata. (Digantara dan Kurniawan ; Sosialisasi Cara Penanggulangan Perubahan Perilaku Sosial Anak Akibat Bermain Gawai
Secara Berlebihan. Diakses pada 28 Febuari 2017).

Penelitian ini sejalan dengan Kim (2013) menyatakan bahwa penggunaan media digital memiliki efek terhadap kemampuan perhatian anak seperti peningkatan hiperaktivitas dan kesulitan dalam berkonsentrasi serta mereka juga lebih banyak merasa sedih atau bosan dengan teman-temannya. (Yulia Trinika, 2015).

\section{Kesimpulan}

Berdasarkan hasil analisis yang telah dilakukan oleh peneliti, diperoleh kesimpulan sebagai berikut :

1. Tidak Terdapat Hubungan Yang Signifikan Antara Penggunaan Gadget di Rumah Dengan Perkembangan Sosial Emosional Anak Usia 3-5 Tahun di PAUD Dellia Creative School.

2. Berdasarkan hasil penelitian kontribusi antara penggunaan gadget di rumah dengan perkembangan sosial emosional anak sebesar 0,0441 yang artinya korelasi sangat rendah.

3. Besar hubungan antara penggunaan gadget di rumah dengan perkembangan sosial emosional anak usia 3-5 tahun berdasarkan perhitungan korelasi product moment 
dengan rumus $r_{\text {hitung adalah sebesar }}$ 0,21. Artinya korelasi sangat rendah.

\section{Referensi}

Andrian, Romadhon, Dery. 2005. Pengaruh Gadget terhadap Perkembangan Anak Usia Dini. Dalam website (https://www.scribd.com/doc/3161617 09/Pengaruh-Gadget-terhadapPerkembangan-Anak-Usia-Dini). Diakses pada 10 Oktober 2016.

Arifn, Zainal. 2012. Evaluasi Pembelajaran. Bandung : PT Remaja Rosdakarya. Arikunto, Suharsimi. 2006. Prosedur Penelitian Suatu Pendekatan Praktik. Jakarta: PT. Rineka Cipta.

Dellia Creative School 2016-2017

Depdiknas. (2009). Peratutan Menteri Pendidikan Nasional Nomor 58. Jakarta: Direktorat PAUD. Fudyartanta, Ki. (2011). Psikologi Perkembangan. Yogyakarta: Pustaka Pelajar Hasbullah. 2013. Dasar-dasar Ilmu Pendidikan. Jakarta: PT. Raja Grafindo Persada

Hasto Prianggoro (2016). Anak dan Gadget: Yang Penting Aturan Main. Diakses pada 17 oktober 2016, dari http://www.tabloidnakita.com/read/1/anak-dangadget-yang-penting-aturanmain.html.

Hidayat, A. A. (2009). Pengantar Ilmu Keperawatan Anak 1. Jakarta: Salemba Medika. http://iznanew.blogspot.com/2011/09/me tode-pengembangan-perilaku-dan.html (10 Oktober 2016)

Iis, Widiawati. dkk. 2014. "Pengaruh Perkembangan Gadget Terhadap Daya Kembangan Anak". Prosiding Seminar Nasional Multidisiplin Ilmu, Jakarta 10 Mei, hal.:106-112.
Internet Sehat, 2012. 7 dari 10 Anak Ikut Pakai Gadget Orangtuanya. Diakses pada 10 Oktober 2016, dari : http://ictwatch.com/internetsehat/2012 /05/21/7-dari-10-anak-ikut-memakaigadget-orangtuanya/.

Karman. (2013). Riset Penggunaan Media dan Perkembangannya Kini . Jurnal Studi Komunikasi dan Media, Vol.17, No.1.

Masitoh, dkk. Strategi Pembelajaran TK, Jakarta 2007, Universitas Terbuka.

Maulida, Hidayahti. 2013. Menelisik Pengaruh Penggunaan Aplikasi Gadget Terhadap Perkembangan Psikologis Anak Usia Dini. Jurnal Ilmiah Teknologi Pendidikan 2013. FKIP Universitas Negeri Semarang.

Okezone. (2013). "Tiap Hari, 17\% Anak Main Gadget." Dalam website (http://berita.plasa.msn.com/article.asp $\mathrm{x}$ ?cp-documentid=254350783).

Diakses pada 9 November 2016.

Profil Paud Dellia

Rahman, Ulfiani. (2009). "Karakteristik Perkembangan Anak Usia Dini”, Jurnal Lentera Pendidikan Vol.12, No.1, Juni, hal. 46-57.

Riduwan. 2013. Dasar-dasar Statistika. Bandung: Alfabeta

Rofiati, Hamdiyah. 2012. Pengaruh Teknologi Gadget Terhadap Perkembangan Mental Anak-anak Indonesia. Universitas Erlangga.

Sekaran, Uma. 2006. Metode Penelitian Bisnis. Jakarta : Salemba Empat.

Siregar, Syofian. 2014. Statistika Deskriptif untuk Penelitian. Jakarta: PT Grafindo Persada.

Siti Aisyiyah, dkk. Perkembangan dan Konsep Dasar Pengembangan Anak Usia Dini. Jakarta 2007, Universitas Terbuka.

Soetjiningsih, Christiana Hari. 2012. Perkembangan Anak. Jakarta : Prenada Media Grup 
Sugiyono. 2006. Metode Penelitian

Kuantitatif Kualitatif dan $R \& D$.

Bandung: Alfabeta

Sujiono, Yuliana Nurani. 2009. Konsep

Dasar Anak Usia Dini. Jakarta : PT. indeks

Trinika, Yulia (2015). Pengaruh

Penggunaan Gadget Terhadap

Perkembangan Psikososial Anak Usia

Prasekolah (3- 6 Tahun) Di Tk Swasta

Kristen Immanuel Tahun Ajaran 2014-

2015. Pontianak : Fakultas

Kedokteran, Universitas Tanjungpura.

Undang-Undang RI No. 20 Tahun 2003.Tentang Sistem Pendidikan

Nasional.Jakarta : Cemerlang

Widiawati \& Sugiman. 2014. Pengaruh

penggunaan gadget terhadap daya

kembang

anak.Diaksesdarihttp://stmikglobal.ac.

$\mathrm{id} /$ wpcontent/uploads/2014/05/ARTIK

ELIIS.pdf pada tanggal 20 April 2017.

Wijana, Widarmi,dkk. 2012. Kurikulum

Pendidikan Anak Usia Dini.

Tanggerang Selatan : Universitas

Terbuka.

Wikipedia. (2013). "Gadget" diunduh dari

(http://id.wikipedia.org/wiki/Gadget), pada 17 Oktober 2016.

Winarni, Endang W. 2011. Penelitian

Pendidikan. Bengkulu: Putri Media. 